\title{
Facebook as a tool to learn English vocabulary
}

\section{Facebook como herramienta para aprender vocabulario en inglés}

\author{
FLORES-GONZÁLEZ, Norma†, CASTELAN-FLORES Vianey, ZAMORA-HERNÁNDEZ, Mónica y \\ FLORES-GONZÁLEZ, Efigenia
}

Benemérita Universidad Autónoma de Puebla, Facultad de Lenguas.

Benemérita Universidad Autónoma de Puebla, Preparatoria Regional Enrique Cabrera Barroso.

ID $1^{\text {er }}$ Autor: Norma, Flores-González /ORC ID: 0000-0002-4967-8854, Researcher ID Thomson: S-6917-2018, CVU CONACYT ID: 957036

ID $1^{\text {er }}$ Coautor: Vianey, Castelán-Flores / ORC ID: 0000-0001-8687-2552

ID $2^{\text {do }}$ Coautor: Mónica, Zamora-Hernández / ORC ID: 0000-0002-7012-4805

ID $3^{\text {er }}$ Coautor: Efigenia Flores-González / ORC ID: 0000-0002-8340-9340, Researcher ID Thomson: S-5923-2018, CVU CONACYT ID: 333959

DOI: $10.35429 / J T E R .2019 .16 .5 .10 .19$ Received September 02, 2019; Accepted December 30, 2019

\begin{abstract}
Nowadays, the integration of social networking sites (SNS) into the education field, like Facebook, has changed the way people communicate with each other and created new learning approaches. Therefore, the importance of implementing pedagogical strategies for English language learning (ELL) to create new learning classrooms either physical or virtual should be privileged this time. The objectives of this research article are to know if the Facebook tool helps students to learn vocabulary in English, and identify what learning strategies they use to learn vocabulary meanwhile interacting with this tool. Thus, the research questions are: 1 . Does Facebook allow students to learn vocabulary in English? 2. What learning strategies do students use to learn vocabulary when interacting on facebook? Concerning methodology, the research was accomplished by using a quantitative method with a cross-sectional design and a Likert scale questionnaire. The results showed that Facebook is useful to learn not only vocabulary but also English language since students used the vocabulary in authentic, natural, and meaningful contexts. Besides, it provides important data to identify different strategies used to learn vocabulary because this social network became part of their learning process.
\end{abstract}

Facebook, Vocabulary, Learning strategies, English as a Foreign Language

\begin{abstract}
Resumen
Hoy en día, la integración de los sitios de redes sociales (SRS) en el campo de la educación, como Facebook, ha cambiado la forma en que las personas se comunican entre sí y ha creado nuevos enfoques de aprendizaje. Por lo tanto, la importancia de implementar estrategias pedagógicas para el aprendizaje del idioma inglés (ELL) para crear nuevas aulas de aprendizaje, ya sea físicas o virtuales, debe ser privilegiada en este momento. Los objetivos de este artículo de investigación son saber si la herramienta de Facebook ayuda a los estudiantes a aprender vocabulario en inglés e identificar qué estrategias de aprendizaje usan para aprender vocabulario mientras interactúan con esta herramienta. Por lo tanto, las preguntas de investigación son: 1. ¿Facebook permite a los estudiantes aprender vocabulario en inglés? 2. ¿Qué estrategias de aprendizaje usan los estudiantes para aprender vocabulario cuando interactúan en Facebook? Con respecto a la metodología, la investigación se realizó mediante el uso de un método cuantitativo con un diseño transversal y un cuestionario de escala Likert. Los resultados mostraron que Facebook es útil para aprender no solo el vocabulario sino también el idioma inglés, ya que los estudiantes usaron el vocabulario en contextos auténticos, naturales y significativos. Además, proporciona datos importantes que contribuyen a identificar diferentes estrategias utilizadas para aprender vocabulario porque esta red social se convirtió en parte de su proceso de aprendizaje.
\end{abstract}

Facebook, Vocabulario, Estrategias de aprendizaje, Inglés como lengua extranjera

Citation: FLORES-GONZÁLEZ, Norma, CASTELAN-FLORES Vianey, ZAMORA-HERNÁNDEZ, Mónica y FLORESGONZÁLEZ, Efigenia. Facebook as a tool to learn English vocabulary. Journal of Teaching and Educational Research. 2019. 5-16: $10-19$

\footnotetext{
* Correspondence to the Author: (norma-fg@hotmail.com)

$\uparrow$ Researcher contributing as first Author
} 


\section{Introduction}

When learning English as a Foreign language, most of the times students face problems to learn and speak it meanly due to lack of vocabulary, which is an essential component in any language as it is the case at the Faculty of Language at the Benemérita Universidad Autónoma de Puebla (BUAP) where students of intermediate level experienced problems like understanding unknow words, using phrasal verbs, idioms, fixed word collocations., and in general, learning vocabulary. In fact, language learning depends on many tools, methods, and techniques to achieve its goal (Richards \& Rodgers, 2014). Among some of these tools is the usage of Facebook in which users find pages for different purposes.

In Mexico, Facebook is used a lot; however, its usage is related to informal communication rather than as an education tool. Moreover, there are few empirical studies about it (Milosevic, Zivkovic, Arsic, \& Manasijevic, 2015). According to Pew Research Center (2014), facebook is the most used social network, with approximately $71 \%$ of total Internet users and mostly used by young people (Araujo and Cabero, 2014). There is evidence that it does provide sharing educational content that generates an impact on both learners and society. Concerning this point, the present study is justified because of practical, theoretical, methodological, and social justifications. In the coming lines, they are described.

Practically, it will solve a real problem. Theoretically, it will contribute by the identification of suitable learning strategies to learn vocabulary by using Facebook as a pedagogical tool. Methodologically, it will lead to a way of analyzing the usefulness of Facebook to learn vocabulary. Lastly, socially, it will give an idea to society about applying SNS for educational purposes.

On one side, it is relevant and suitable because the gotten data could be taken as a reference point to apply this study in different educational fields to improve the learning process of English, especially vocabulary. On the other side, the objectives that will guide the present research are: to know if the Facebook tool helps students to learn vocabulary in English, and identify what learning strategies they use to learn vocabulary meanwhile interacting with this tool.
From the above objectives underlie the following research questions:

1. Does Facebook allow students to learn vocabulary in English?

2. What learning strategies do students use to learn vocabulary when interacting on facebook? follows:

Finally, the hypothesis is enunciated as

H1. Facebook helps students to learn vocabulary in English.

\section{Theoretical framework}

In Mexico, the learning process of English is focused on two main components: structure and vocabulary, having more importance grammatical structures. However, how could it be possible to learn grammar without knowing vocabulary? How can language be used by itself without words? If a student knows words, he could express his ideas clearly and fluently (Linse, 2006).

Thus, if language takes place is because there is enough vocabulary to operate it. Then, the necessity of strategies to learn it arises. Fortunately, currently, there are different digital tools that foster vocabulary in an adjustable and ideal atmosphere (Huyen and Nga 2003) by satisfying students' interests and demands. As a matter of fact, English language vocabulary growth is feasible because a learner could access to a number of online sources while they are sharing information (Blood, 2000; Kajder and Bull, 2004; Dyrud, Worley and Flatley, 2005).

Moreover, the use of social networks such as Facebook allows the development of student-centered teaching practices with a communicative approach in real situations that demand users' language proficiency and considerable baggage of vocabulary to communicate (Fernández, 2019).

\section{Facebook as a SNS}

The social networks including Facebook allow users to place language learning in an authentic community or in social contexts that go beyond the classroom, essential for meaningful learning (Gee, 2004).

FLORES-GONZÁLEZ, Norma, CASTELAN-FLORES Vianey, ZAMORA-HERNÁNDEZ, Mónica y FLORES-GONZÁLEZ, Efigenia. Facebook as a tool to learn English vocabulary. Journal of Teaching and Educational Research. 2019 
Taking into account Ferdig (2007) social media, like Facebook, requires learners to interact during the language learning process if it is used for those purposes. During that communication act, they share knowledge in an authentic and natural context with frequency usability (Pavlik et al, 2015) as well as points of view to develop social relations with other users, whose accent is different (Gaudeul and Peroni, 2010). By using these SNS, students establish a sense of belonging to a community that is helpful for English language learning and vocabulary development (Goodwin-Jones, 2003).

Facebook has a crucial role in English language learning because it provides opportunities to English language learners to improve their skills like reading and writing while interacting with texts and phrases to improve their vocabulary baggage. Furthermore, Facebook and in general social networking sites allow language teachers to expand learning outside classrooms, activate reflective thinking, build up knowledge, and foster ELL while consolidating relationships between students (Mahadi and Ubaidullah, 2010; Idris and Ghani, 2012)

Regarding Weimer (2009), the learning environment gives relevant content, feedback, clear goals and opportunities to construct social skills like facebook. However, this tool by itself is not enough to learn vocabulary even though it provides students with a lot of facilities. It is necessary to look for vocabulary learning strategies (VLSs) too. First of all, it is necessary to make a distinction between receptive and productive vocabulary. The former deals with the vocabulary used in both reading and listening skills, which could be less demanding for students since it only asks for recognizing them. The latter "requires the learners to use the word appropriately in new contexts" (Nation, 2001, p. 43).

Thus, regarding the previous information, students need specific strategies to learn written vocabulary. Since vocabulary is a linguistic competence, it requires learning strategies to be grasped by students. At this point, Michelle and Myles (2004, p. 24) claims that "the initial initiative in learning a second language is known as the controlled processing, this step involves activating the selection of information nodes in the memory".

\section{Vocabulary learning strategies}

VLSs are techniques that students use in order to learn vocabulary. Taking into account O'Malley and Chamot (1990, p. 1) VLSs are "the special thoughts or behaviors that individuals use to help them comprehend, learn, or retain new words". Considering Flores, García, and Pérez (2019), there are applications to learn vocabulary like the Memrise app, which was applied as a metacognitive digital strategy to understand texts for specific purposes.

This app is based on some functions through which the VLSs are developed. They are learning new words, classic review, speed review, difficult words, listening skills and meet the natives.

As a matter of fact, there are different VLSs. On one hand, according to Nation (2001), three categories are identified: planning, sources, and process. On the other hand, Wong (2014, p. 18) points out five categories to learn vocabulary which are "Determination, Social, Memory, Cognitive and Metacognitive strategies".

Some other authors suggest a more complete model of VLSs:

1. Defining words within context. This strategy is applied at the moment when the learner meets the word and implies to look for its meaning in order to understand (Biemiller and Boote, 2006).

2. Sketching the words or using visuals. Students connect the new word to their personal drawing in order to make it meaningful and remember the word (Nagy, 2005). Indeed, visual materials lead the opportunity to share content, visualize and learn the new vocabulary of the English language (Valero, 2009).

3. Applying Target Words. Use the target words in everyday learners' speeches as possible. It will help them to apprehend those words. (Wasik and IannoneCampbell as cited in Douglas and Frey, 2014)

4. Semantic mapping. This strategy helps students by connecting the new word with a synonym, antonym, and at the same time, they increase their vocabulary (Baumann, Kame'enui, and Ash, 2003). 
5. Using context clues. By using inference base don the cotext, learners can get the meaning of a new word (Nagy and Scott, 2000).

It is worthy to mention that for the present study, the model above would be taken into account.

\section{Methodology}

This research is based on a quantitative study with a cross-sectional design.

According to Skinner in Ugalde and Balbastre (2013), the quantitative study allows the use of predetermined categories that provides the data obtained to be subjected to statistical analysis. That is why this method was selected because it was necessary to look for series of general patterns that characterize the sample of this study.

In order to operationalize the variables and analyze this phenomenon, a questionnaire of 20 items was designed based on the Facebook general usage to know if the tool helps students to learn vocabulary in English, and identify what learning strategies they use to learn vocabulary meanwhile interacting with this tool.

The questionnaire has an additive Likertscale of agreement with an ordinal level, consisting of a series of items to which the subject's reaction is requested (Namakforoosh, 2000). Related to its validity it was done with the SPSS software, getting its reliability and validity.

The sample of the study is comprised of 40 subjects who are students in the Bachelor of English Teaching at the Faculty of Languages at BUAP. This sample shares some characteristics: They are intermediate students and use Facebook to learn English vocabulary.

Talking about the data collection, the printed-version questionnaires were applied at the same time to the whole population. The analysis of the data was based on the model analysis below.

\begin{tabular}{|c|c|c|}
\hline Instrument & Dimension & Items \\
\hline $\begin{array}{l}\text { Variable } 1 \\
\text { Does Facebook } \\
\text { allow students to } \\
\text { learn vocabulary } \\
\text { in English? }\end{array}$ & $\begin{array}{l}\text { Students' } \\
\text { perceptions } \\
\text { towards the use } \\
\text { of Facebook to } \\
\text { learn vocabulary }\end{array}$ & $\begin{array}{l}1,3,5,7,9,11 \\
13,15,17,19\end{array}$ \\
\hline $\begin{array}{l}\text { Variable } 2 . \\
\text { What learning } \\
\text { strategies do } \\
\text { students use to } \\
\text { learn vocabulary } \\
\text { when interacting } \\
\text { on facebook? }\end{array}$ & $\begin{array}{l}\begin{array}{l}\text { Identification } \\
\text { of VLSs: } \\
\text { Defining words } \\
\text { within context }\end{array} \\
\text { Sketching the } \\
\text { words or using } \\
\text { visuals } \\
\text { Applying Target } \\
\text { Words. } \\
\text { Semantic } \\
\text { mapping } \\
\text { Using context } \\
\text { clues }\end{array}$ & $\begin{array}{l}2,4,6,8,10, \\
12,14,16,18, \\
20\end{array}$ \\
\hline
\end{tabular}

Table 1 Vocabulary Learning Strategies based on Biemiller and Boote, 2006; Nagy, 2005; Wasik and Iannone-Campbell as cited in Douglas and Frey, 2014; Baumann, Kame'enui, and Ash, 2003; Nagy and Scott, 2000

\section{Findings}

With the data obtained by the subjects, two variables with their respective dimensions will be analyzed to prove the two research questions and the hypothesis established at the beginning of this study:

\section{Variable 1. Facebook helps to learn vocabulary}

In this variable, three main dimensions were observed to characterize the subjects' perceptions towards the use of Facebook to learn vocabulary based on the ten items.

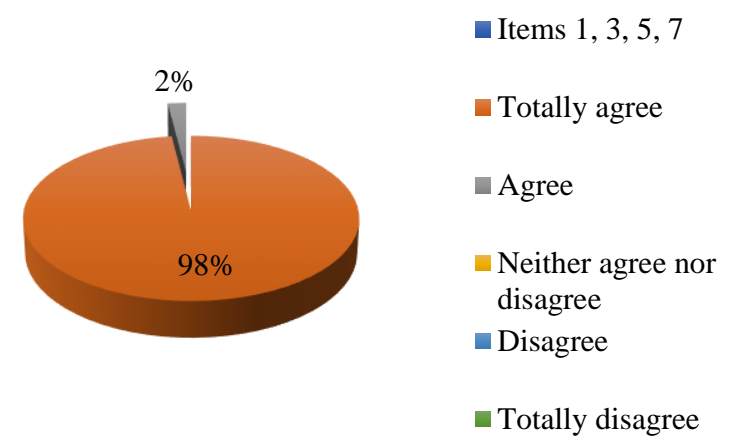

Graphic 1 Facebook allows subjects to learn vocabulary 
As can be observed, $98 \%$ of the subjects totally agreed while 2\% agreed that Facebook is a useful tool that helps them to learn vocabulary. They reported having learned not only words but also grammar structures and parts of speech in their engagement to facebook. Besides, they learned terminologies and acronyms, which are not commonly used in academic language or books.

Another important characteristic was that they perceived Facebook as a social interaction practice that allowed them to code and decode to restate meanings with authentic content. Based on the information above, it could be claimed that the informal learning environment provided by Facebook as social networks, subjects found unexpected and meaningful learning experiences with a variety of resources to learn vocabulary.

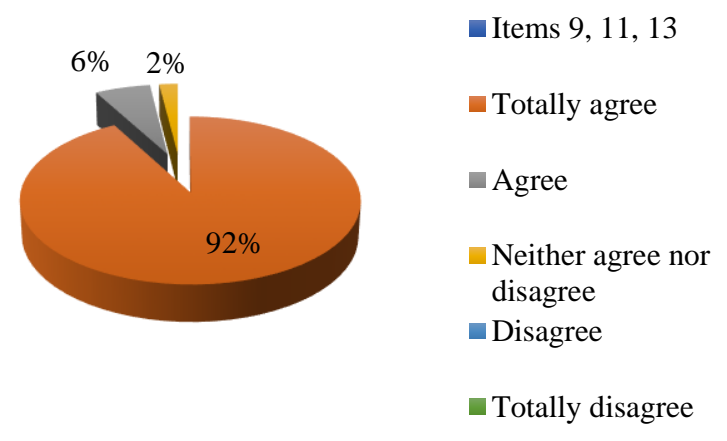

Graph 2 Facebook lets subjects to learn vocabulary easily

The graphic shows a high positive subjects' perception to the use of facebook since $92 \%$ of the sample totally agreed, $6 \%$ agreed and only $2 \%$ neither agree nor disagree with the perception that Facebook lets subjects to learn vocabulary easily. As a matter of fact, they stated that it is easy to remember vocabulary since they are engaged in it every day.

They also declared this tool as one that enabled them to empower and participate actively by interacting and sharing knowledge. In other words, they see it as ICTs for Empowerment and participation.

The above is supported by RománMendoza in Santos and Alamán (2019) who think of educational technologies as tools that allow autonomy and active collaboration. As can be seen, the subjects found interest in this tool since, as Araujo and Cabero (2014) mentioned, it is a tool to which the majority of students have access and use every day to communicate.
According to subjects' perceptions, another feature of the Facebook tool that facilitates the learning of the lexicon was that it pushes them to practice new words in a real natural context as many times as they want to. Even with people whose accent is different.

Regarding that, Imbernón, Silva, and Guzmán (2011) affirmed that this tool provides a more interactive and dynamic learning space that vocabulary learning takes place easier and faster with self-confidence and motivation.

Indeed, $92 \%$ of the subjects agreed that Facebook promoted motivation and engagement in language learning contexts as Blattner and Anderson (2012) affirmed.

Another important finding related to the easiness of learning vocabulary according to subjects' perceptions was that the tool provides a learning process based on students'autonomy and rhythm control as Kaplan-Rakowski in Melchor (2014) claimed.

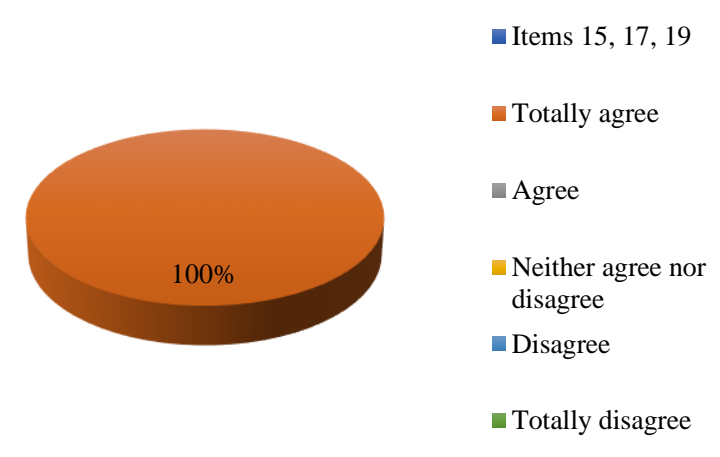

Graphic 3 Learning vocabulary with facebook leads to foster other skills and culture

According to the results, $100 \%$ of the sample totally agreed by expressing a positive perception towards Facebook as a tool that not only helps to learn vocabulary but also comprehension and writing skills, listening and oral competences, grammar, critical thinking and in general English language proficiency with high motivational levels by performing actively. This asseveration confirmed what Farias (2012) mentioned about all applications and social media, which demand users for active participation in two scenarios. The former to create or produce content and the latter to share and interact even with native speakers. Considering this fact, Rincon (2009: 79) states that "Facebook is changing the way people interact in society, to the point of having become a bridge that allows interactions with a large group of people, at different levels of closeness and familiarity".

FLORES-GONZÁLEZ, Norma, CASTELAN-FLORES Vianey, ZAMORA-HERNÁNDEZ, Mónica y FLORES-GONZÁLEZ, Efigenia. Facebook as a tool to learn English vocabulary. Journal of Teaching and Educational Research. 2019 
The subjects also assured that when learning vocabulary on Facebook, they learned culture because it was included in any messages or conversation they had with natives or nonnatives. In this regard, Williams and Burden as cited in Ainciburu and Buttazzi (2019, p. 102) states that "learning a language implies much more than simply learning skills or a system of norms or grammar; it implies the adoption of new cultural behaviors". Other authors that share the same point of view are Jerez and Nava (2019), who mentioned that the use of social networks are sources of reading and writing that provide interactions with a real audience, facilitating cultural exchanges that allow users to improve language performance.

Moreover, subjects totally agreed that this tool is a virtual place where they can find pages to learn vocabulary with other applications thanks to the advantages that it offers to its users. Additionally, $100 \%$ of the sample perceived facebook as a digital tool or technology to learn and a source to construct knowledge to be proficient in the language. In relation to this, Castañeda in González, Ureta, Marcovecchio, Margarit, Pontoriero, Rossetti, and Villodre (2019) confirmed this perception since they considered the technologies for learning and knowledge like new ways to make a new school model which respond to the training needs of citizens.

Variable 2. Learning strategies students use to learn vocabulary when interacting on Facebook.

To answer the second research question and prove or refute the hypothesis mentioned in the introduction, the variable learning strategies students use to learn vocabulary when interacting on Facebook is analyzed.

In this variable, the VLSs are pointed out according to subjects' answers based on ten items and level of agreement as followed:

5 Totally agree

4 Agree

3 Neither agree nor disagree

2 Disagree

1 Totally disagree

\begin{tabular}{|l|r|r|r|r|r|}
\hline & \multicolumn{5}{|c|}{ Level of agreement } \\
\hline Strategy words & $58 \%$ & $40 \%$ & $2 \%$ & $0 \%$ & $0 \%$ \\
\hline $\begin{array}{l}\text { Defining } \\
\text { within context }\end{array}$ & $94 \%$ & $6 \%$ & $0 \%$ & $0 \%$ & $0 \%$ \\
\hline $\begin{array}{l}\text { Sketching the words } \\
\text { or using visuals }\end{array}$ & $80 \%$ & $20 \%$ & $0 \%$ & $0 \%$ & $0 \%$ \\
\hline $\begin{array}{l}\text { Applying the Target } \\
\text { words. }\end{array}$ & $100 \%$ & $0 \%$ & $0 \%$ & $0 \%$ & $0 \%$ \\
\hline Semantic mapping & $46 \%$ & $54 \%$ & $0 \%$ & $0 \%$ & $0 \%$ \\
\hline Using context clues & & & & \\
\hline
\end{tabular}

Table 2 Learning strategies students use to learn vocabulary when interacting on Facebook

As can be seen, the table establishes that taking into account the students' perceptions, five vocabulary learning strategies were identified while they were interacting on facebook.

Concerning the first VLS, only $2 \%$ neither agreed nor disagreed with the usefulness of this strategy, which means that the majority of the sample perceived it as important for increasing vocabulary.

$58 \%$ of the sample totally agreed that defining words within context helps them to memorize the word and in the long-term, learn it. Another facility to apprehend new words and enrich their lexical baggage, specially slangs and phrasal verbs, was the opportunity to use the new word in different authentic contexts and real situations.

$40 \%$ agreed that this strategy let them learn lexicon due to the following reasons:
a. Words are stored in the long-term memory

b. users became expertise by guessing the meaning of new words in context

c. they learn more vocabulary about the new word such as synonyms, antonyms, and parallel phrases actively.

Talking about the second VLS (sketching the words or using visuals) $94 \%$ totally agreed that learning vocabulary is better if they added a visual aid to remember it such as pictures or labels. Furthermore, 6\% agreed to $\mathrm{Kim}$ and Gilman's (2008) asseveration about the successfulness of this strategy because it allowed subjects to have the picture-word pairing visual strategy whose graphics were appropriate and relevant to the vocabulary words they represent. 
Another strategy found crucial to learn vocabulary with facebook was applying the Target words. Regarding this, on one hand, $80 \%$ totally agreed that this strategy promotes active and deep processing of word meanings while sharing information on Facebook. In fact, ongoing interactions provided subjects with many opportunities to target words which affect positively to their long term memory storage.

On the other hand, $20 \%$ mentioned that the clear related definitions and examples provided in the target language were crucial to learn vocabulary and even enrich it. As been analyzed in the table, the whole sample agreed with some level with the helpfulness of this strategy.

About semantic mapping, which was the fourth strategy used by the sample, $100 \%$ of the subjects stated that this visual strategy allowed them to show relationships between known and unknown words by adding synonyms and antonyms to the target vocabulary. They recognized this tool as a way to identify, understand, and recall the meaning of unknown words they read or listened to

They also mentioned that this strategy promoted collaborative work in facebook since to get meaningful word relations, the subjects involved in the interaction added more words to build up a diagrammatic map and associated as much vocabulary as possible, having as a result, a semantic mapping that showed graphically information related to a new word. In general, they perceived this strategy as schemata in the learning process.

Finally, the last strategy, called using context clues was found by $46 \%$ of the sample as a form to get the meaning of an unknown word and retain them in the long-term memory.

They were aware of the context importance due to its usefulness to understand the target language and later, use it correctly.

54\% agreed that context clue strategy was suitable to potentiate their language abilities. Indeed, their exposure to comprehensible input guided them to assimilate and learn high-rate of vocabulary baggage crucial for their proficiency language as speakers.
These results proved that it is possible to understand the meaning of a new word without depending on an extra source like dictionaries. In this way, they avoided investing extra time in searching for meanings of a specific lexicon if they applied this strategy.

Generally, the previous five strategies were found as the main ones used by the sample to learn vocabulary when interacting on Facebook. Besides, they perceived them as positive ways to learn the meaning of vocabulary. In the following lines, the conclusions are drawn.

\section{Conclusions}

Based on the responses of the subjects and the analysis of results, it is possible to conclude that Facebook is a tool that has helped to learn vocabulary in English to the sample been described.

The results proved the two research questions by affirming that facebook does allow users to learn vocabulary in English, and the VLSs leaners used to foster it in facebook are: defining words within context, sketching the words or using visuals, applying Target words, semantic mapping and using context clues.

Focussing on the about asseverations, the hypothesis of this study was proven too. Additionally, by using Facebook as a means of learning English vocabulary, subjects could subsequently apply what they learn in their classes. This helped them to continue expanding their vocabulary since it was a social network that they used extremely frequently.

Another conclusion is that they considered facebook as a tool to promote technologies of empowerment and participation as well as technologies for learning and Knowledge, which are the main clues for current educational models.

Taking about the sample (university students), it was found that Facebook (SNS) played a vital role in the development of English language vocabulary at the university level. Thanks to the usage of different varieties of VLSs, they realized that the only way a student could learn and have rich vocabulary was by experiencing them; otherwise, they would only memorize long lists of words meaningless. 
At the same time, they gained autonomy and motivation, important elements in the learning-teaching process. Finally, it is worthy to mention that this research could guide future researchers on the methodology of learning English vocabulary and in general language as well as helps them design an appropriate interactive multimedia learning, which could be in a virtual or blended learning modality.

\section{References}

Ainciburu, M. C., Buttazzi, I. (2019). Las palabras de la identidad en el ámbito laboral. Elecciones léxicas y preferencias temáticas de las mujeres inmigrantes de Madrid. España: Universidad de Alcalá.

Araujo, J.C. (2014). El uso de blogs, wikis y redes sociales en la enseñanza de lenguas. Edutec. Revista electrónica de tecnología educativa. 49, 1-27.

Baumann, J. F., Kame'enui, E. J., Ash, G. E. (2003). "Research on vocabulary instruction: Voltaire redux," in J. Flood, D. Lapp, J. R. Squire, and J. M. Jensen (eds.), Handbook of research on teaching the English language arts, 2nd ed., Mahwah, NJ: Erlbaum.

Baumann, J. F., Kame'enui, E. J., Ash, G. E. (2003). "Research on vocabulary instruction: Voltaire redux," in J. Flood, D. Lapp, J. R. Squire, and J. M. Jensen (eds.), Handbook of research on teaching the English language arts, 2nd ed., Mahwah, NJ: Erlbaum.

Biemiller, A., Boote, C. (2006). “An effective method for building meaning vocabulary in the primary grades," Journal of Educational Psychology, Vol. 98, No. 1, pp. 44-62.

Blattner, G., Anderson, L. (2012). Facebooking and the Social Generation: A New Era of Language Learning. Alsic. DOI: 10.4000/alsic. 2413.

Blood, R. (2000). Weblogs: A history and perspective. Rebecca's Pocket, 7(9). Retrieved on November, 17, 2012 from http://www.rebeccablood.net/essays/weblog_hi story.html.
Cabero, J. \& Marín, V. (2014). Posibilidades educativas de las redes sociales y el trabajo en grupo. Percepciones de los alumnos universitarios. Comunicar. Revista Científica de Edocomunicación, 42(XXI), 165-172.

Douglas, F., Frey, N (2014). Content Area Vocabulary Learning. The Reading Teacher, 67(8), 594-599. Doi: 10.1002/trtr.1258.

Dyrud, M. A., Worley, R. B., \& Flatley, M. E. (2005). Blogging for enhanced teaching and learning. Business Communication Quarterly, 68(1), 77-80.

Farias, P., Gómez, M. y Roses, S. (2012). El uso académico de las redes sociales en universitarios. Comunicar, 1, 1-8. Doi: 10.3916/C38-2011-03-04.

Ferdig, R. E. (2007). Examining social software in teacher education. Journal of Technology and Teacher Education, 15(1), 5-10.

Fernández, L. M. P. (2019, March). Aplicación de mundos virtuales para la enseñanza de lenguas extranjeras en la educación superior. In Conference Proceedings EDUNOVATIC 2018: 3rd Virtual International Conference on Education, Innovation and ICT (p. 387). Adaya Press.

Flores, N., Garcia, E., Pérez, C. (2019). Learing lexicon with a meta-cognitive digital strategy to understand texts for specific purposes in English. México: Benémerita Universidad Autónoma de Puebla.

Gaudeul, A.; Peroni, C. (2010). Reciprocal attention and norm of reciprocity in blogging networks. Economics Bulletin, 30(3), 22302248.

Gee, J.P. (2004). Situated Language and Learning: A Critique of Traditional Schooling. London: Routledge.

González, L. M., Ureta, L., Marcovecchio, M. J., Margarit, V., Pontoriero, F., Rossetti, G., and Villodre, S. L. (2019, June). Alfabetización con formatos múltiples de aprendizaje: las TAC y los nuevos escenarios tecnopedagógicos en la universidad. In XXI Workshop de Investigadores en Ciencias de la Computación (WICC 2019, Universidad Nacional de San Juan). 
Goodwin-Jones, R. (2003). Blogs and wikis: Environments for on-line collaboration. Language Learning and Technology, 7(2), 1216.

Huyen, N. T. T., Nga, K. T. T. (2003). Learning vocabulary through games, the effectiveness of learning vocabulary through games. Asean EFL Journal. Retrieved from http://www.asian-efljournal.com/dec_03_sub.Vn.php.

Idris, H.; Ghani, R.A. (2012). Construction of knowledge on Facebook. 3L: Language, Linguistics, Literature. 18. 61-72.

Imbernón, F., Silva, P., Guzmán, C. (2011). Competencias en los procesos de enseñanza aprendizaje virtual y semi-presencial. Comunicar, XVIII (36), 107-114. doi: 10.3916/C36- 2011-03-01.

Jerez-Rodríguez, S., Navas-Rios, M. E. (2019). Leer, Escribir y Comunicarse en Otro Idioma con Nuevas Prácticas Letradas Fuera del Aula de Clase. Información tecnológica, 30(2), 315-326.

Kajder, S., Bull, G. (2004). A space for "writing without writing.". Learning \& Leading with Technology, 31(6), 32-35.

Kim, D. \& Gilman, D. A. (2008). Effects of text, audio, and graphic aids in multimedia instruction for vocabulary learning. Educational Technology \& Society, 11(3), 114-126.

Linse, C. T. (2006). Practical English Language Teaching: Young Learners. New York. NY: McGraw-Hill.

Mahadi, N., Ubaidullah, N. H. (2010). Social Networking Sites: Opportunities for Language Teachers. International Journal of Learning. 17. 313-324. $10.18848 / 1447-$ 9494/CGP/v17i06/47083.

Melchor, S. (2014). El uso de mundos virtuales para la interaccioón oral en el aula de lenguas extranjeras y su impacto en las variables afectivas. (Tesis doctoral). Universidad de Vigo, Vigo.

Milosevic, I., Zivkovic, D., Arsic, S., Manasijevic, D. (2015). Facebook as virtual classroom - Social networking in learning and teaching among Serbian students. Telematics and Informatics, 32(4), 576-585.
Mitchell, R., Myles, F. (2004). Second Language Learning Theories. London: Hodder Arnold.

Nagy, W. E. (2005). "Why vocabulary instruction needs to be long-term and comprehensive," in E. H. Hiebert and M. L. Kamil (eds.), Teaching and learning vocabulary: Bringing research to practice, Mahwah, NJ: Erlbaum.

Nagy, W. E., Scott, J. A. (2000). "Vocabulary processes," in M. L. Kamil, P. Mosenthal, P. D. Pearson, and R. Barr (eds.), Handbook of reading research, Vol. 3, Mahwah, NJ: Erlbaum.

Namakforoosh (2000). Metodología de la investigación. México: Limusa.

Nation, I. S. P. (2001). Learning vocabulary in another language. United Kingdom: Cambridge University Press.

O’Malley, J. M., Chamot, A. U. (1990). Learning Strategies in Second Language Acquisition. Cambridge, UK: Cambridge University Press.

Pavlik, M., Shawn, J. (2015). Converging Media 4th Edition. New York, NY: Oxford University Press.

Pew Research Center. (2014). Social media update 2014. Recuperado de http://www.pewinternet.org/2015/01/09/socialmedia-update-2014/.

Richards, J.C., Rodgers, T.S. (2014). Approaches and methods in language teaching. England: Cambridge University Press.

Rincón, SA. (2009) Interacción social virtual y comunicación interpersonal en dos escenarios de la Web 2.0: Narratopedia y Facebook. (Tesis de grado en Comunicación). Facultad de Comunicación y Lenguaje Pontificia Universidad Javeriana, Colombia.

Santos, M. D. C. M., \& Alamán, A. P. (2019). Una aproximación al perfil del profesorado de español como lengua extranjera en línea. Revista Internacional de Lenguas Extranjeras/International Journal of Foreign Languages, 2(11). 
Ugalde, N., Balbastre, F. (Julio-Diciembre de 2013). Buscando las ventajas de las diferentes Metodologías de Investigación. Revista de Ciencias Económicas.Vol. 31 (2) 179-187. Costa Rica.

Valero, J. (2009). La transmisión de conocimiento a través de la infografía digital. México: Revista ámbitos DIALNET.

Weimer, M. (2009). Effective Teaching Strategies: Six Keys to Classroom Excellence. Faculty Focus-Higher Education Teaching Strategies from Magna Publications.

Wong, Y. (2014). A Case Study of the Vocabulary Learning Strategy Use of Twenty Chinese ESL Learners in Australia. (Doctor of education thesis). Griffith University, Australia. 